\title{
CRITICAL ROLE OF BRIDGING ORGANIZATIONS IN RIVER BASIN MANAGEMENT IN ALBERTA, CANADA
}

\author{
JUDY STEWART \\ Canadian Institute of Resources Law, University of Calgary, Canada
}

\begin{abstract}
The paper examines bridging and brokerage functions performed by a Canadian watershed-scale bridging organization in Alberta's watershed governance and management system. The Bow River Basin Council (BRBC), a multi-stakeholder bridging organization in the Bow River Basin in southern Alberta, Canada, provides the demonstration context for exploring concepts of bridging organizations and their evolving roles. BRBC performs strategic bridging functions that connect and engage crosssectoral public and private stakeholders who otherwise would not be included in watershed governance or management decision-making processes. BRBC operates at the watershed-scale and plays critical roles as a strategic broker of information, knowledge, values, and power and influence in the region. BRBC provides venues for stakeholder collaboration to resolve complex watershed management problems where solutions are reached by consensus. Stakeholders work together to identify shared community values and issues of common concern. BRBC builds trust relationships, co-generates crosssectoral knowledge, and facilitates social learning to help resolve stakeholder conflicts over the use and management of scarce water resources in the Bow River Basin.
\end{abstract}

Keywords: bridging organization, social-ecological systems, social network analysis, social network mapping, strategic bridging functions, social learning, river basin management.

\section{INTRODUCTION}

River basins are complex, dynamic social-ecological systems (SES) where society and the ecosystem are inextricably connected, co-evolving and co-regulating cross-scalar adaptions [1]. In the context of river basin governance and management in Alberta, Canada, bridging organizations are emergent social-political arrangements that address system dynamics and complexity [2]. Alberta's population continues to grow, notwithstanding recent economic constraints associated with the downturn in the oil and gas industry [3]. Alberta's social and cultural norms continue to adapt to river basin management science that predicts future water scarcity and deteriorating water quality [4]. New standards, codes of practice and regulations for land use development are being imposed by government to keep the state of the environment within Alberta's seven major river basins [5] within desirable bounds [6].

However, ecosystems do not respect human-made geo-political boundaries or cultural norms and practices [7]. River basins, such as the Bow River Basin (the Bow Basin), a tributary to the South Saskatchewan River in southern Alberta continue to evolve and adapt to human interventions and constraints. Dams, weirs and shoreline modifications have been imposed on riverine systems and adjacent landscapes to accommodate human settlement and economic development. Floods and droughts are both unpredictable and imminent due to climate change and human-induced landscape changes throughout the basin [8].

Governing and managing human interactions and use of the land and water in the Bow Basin involves complex and evolving policy and regulatory systems. In 1992, the Bow River Basin Council (BRBC) was appointed by Alberta's Minister of the Environment to evaluate the state of the Bow Basin and provide advice to the Government of Alberta (GOA) on how to address deteriorating water quality south of the City of Calgary's wastewater treatment plant [9]. Originally, BRBC members were appointed by Ministerial Order [9]. Over time, the BRBC emerged as a self-organizing and self-regulating society comprised of self- 
selecting volunteer representatives from the GOA, municipalities, industry, non-government organizations, academia, and the public [9]. BRBC stakeholders are self-interested with competing interests in water and landscape management, but they use consensus decisionmaking processes to address identified common concerns about water quality, water quantity and river basin resilience [9].

The purpose of this paper is to explore the critical role of bridging organizations in river basin management in Alberta using BRBC as the demonstration context. First, Alberta's complex river basin governance and management system is briefly reviewed in the context of legal pluralism. Second, BRBC's social network structure is presented along with the critical bridging and brokering functions $\mathrm{BRBC}$ is able to perform. The paper concludes that $\mathrm{BRBC}$ is structured and functions as a bridging organization, connecting stakeholders who would otherwise not be connected to solve complex river basin management problems. BRBC critical strategic bridging functions have influenced increased municipal participation in several river basin management activities in the basin [2], [10].

\section{ALBERTA'S COMPLEX RIVER BASIN MANAGEMENT SYSTEM}

In the Bow Basin (Fig. 1) where BRBC operates, legal pluralism dominates the complex system for river basin governance and management [10], [11]. Legal pluralism focuses on a multitude of legal orders within one social field, for example how different sectors of society divert and use water in a semi-arid region [11]. Teubner [12] referred to legal pluralism as being "social norms and legal rules, law and society, formal and informal, rule-oriented and spontaneous". Therefore, in situations where legal pluralism dominates, conflict may arise when implementing rules that seem to conflict with established cultural norms and social customs [11]-[13].

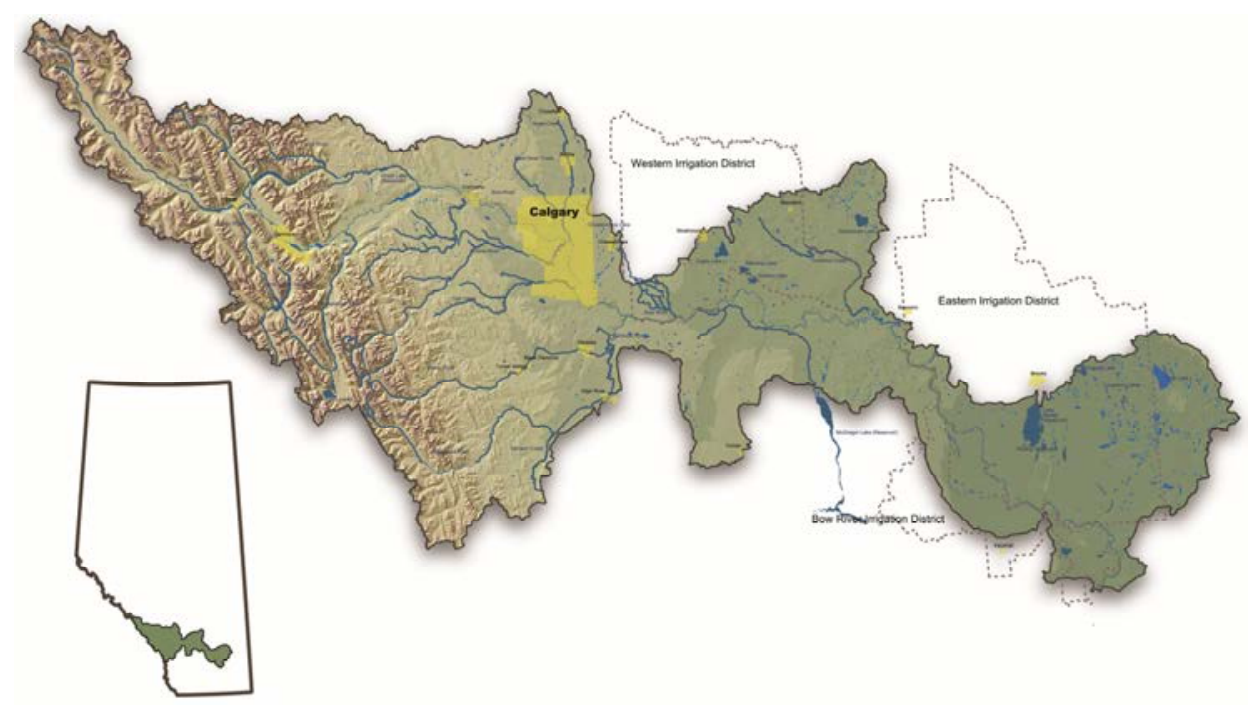

Figure 1: Map of the Bow Basin, Alberta, Canada [9].

Historically, Alberta inherited the British common law system of riparian rights to water, making settlement of the semi-arid region difficult because only those who owned land adjacent to water bodies could divert and use surface water. Settlers could also pump 
groundwater from under the lands they owned to the surface and could store and use it pursuant to the British common-law rule of capture. Over time, as governments and selfinterested corporations across the country encouraged settlement of Alberta's landscape, the GOA claimed ownership and the right to divert and use all surface and groundwater in the province. Water law provisions were enacted to allow the development of complex irrigation reservoirs, weirs and canals to transport water from rivers such as the Bow to dry lands to encourage settlement and agricultural operations. Alberta's first-in-time-first-in-right system of water allocation licenses emerged. Irrigation districts and the City of Calgary were issued large water allocation licenses with no expiry date [1], [9].

With this complex system of water allocation licensing, water approvals to disturb water bodies, environmental laws, and laws to create and regulate irrigation districts and local governments, there are no shortage of provincial policies and laws that affect how water and land are managed in the basin [10], [11]. However, historically, there has been little integration of these multi-jurisdictional, overlapping and sometimes conflicting policies, laws, regulations, codes of practice, guidelines, operating protocols, negotiated rules, municipal statutory planning documents, municipal bylaws, and BRBC's watershed or river basin management plan (RBMP) [10], [11].

Within the GOA, water, air, public and private lands, biodiversity, energy, public health and the economy are all regulated through departmental silos and substantive laws [10], [11]. Several different policies, laws and regulations regulate human diversion and use of water and land use development, depending on whether the land is privately or publicly owned or belongs to the Government of Canada (GOC) [10], [11]. While both water and land are managed as distinct resources or components of the environment [14] there is little integration within the complex system of policy and law. While Water Act [5] provisions provide for the development of water management plans through collaboration with partners, only "approved water management plans" must be considered by the Director when approving water licenses or approvals. There are only two approved water management plans in the province, and one of them exists for the South Saskatchewan River Basin in which the Bow is a significant tributary [15]. Water management plans and watershed or RBMPs are not the same, nor are they integrated in any of Alberta's seven major river basins.

RBMPs, such as BRBC's co-created plan [16] emerge through voluntary stakeholder collaboration. Generally, they reflect GOA's partnership objectives as stated in Water For Life: Alberta's Strategy for Sustainability (Water For Life) [17]. RBMPs are not legal instruments that are enforceable by the courts, although they often recognize and reflect the legal system that exists at the time they are created. Several dozen policies, laws and other legal instruments [10], [11] address how people interact with water and land, but how people interact in river basins is not regulated.

Alberta's current legal regime for both water and land use governance and management has evolved over time as legislatures adapted to emerging social and ecological phenomena [10], [11]. For example, the Municipal Government Act [18] has been amended several times since the mid-1990s with many significant amendments enacted between 2015 and 2018 that affect how municipalities may address local and transboundary environmental matters [18], [19].

The GOA has delegated to municipalities the authority to create policies and enact bylaws to regulate and control environmental matters within their boundaries, as long as the local policies and bylaws do not conflict with provincial or federal enactments [18], [19]. Every municipality in the Bow Basin has enacted municipal land use plans and land use bylaws. In addition, some municipalities have water conservation policies and bylaws, as well as water distribution and pricing bylaws in place. Some have enacted bylaws to prohibit, or regulate 
and control inappropriate land uses that may negatively impact water resources within their boundaries [10]. All of the municipalities in the Bow Basin voluntarily participate in several water resource management activities [10].

In addition to provincial and municipal policies, laws, regulations, bylaws, codes of practice, guidelines and best practices, federal laws enacted by the GOC supersede all other legal instruments that address similar subject matter. For example, there are federal laws that regulate boating, inland fisheries, habitat for species at risk and migratory birds, and environmental impact assessments on federal lands [10]. Nonetheless, regulatory gaps between federal, provincial and municipal laws persist at the river basin scale where no one level of government has sole jurisdiction [9]-[11].

In a situation of legal pluralism like this, conflicting demands, different scales, and cultural orientations may cause uncertainty for individuals who cannot be sure which rules will apply in a specific situation [13]. Self-interested groups and individuals may forum-shop to select rules that advance their personal or corporate objectives, posing challenges to different legal authorities who all claim jurisdiction over the subject matter [13], for example development of wetlands or riparian corridors, or along shorelines and flood risk areas that provide critical habitat for fish, migratory birds and endangered species [19].

Luhmann [20] suggested that any legal system is a self-regulating subsystem of society that functions to stabilize normative expectations of all the other social subsystems, for example, politics, science and economics. Practically speaking, the legal subsystem of any society defines what comprises the law [20]. In this context, RBMPs that are co-created by multi-stakeholder volunteer organizations such as BRBC are not law. The organizations have no delegated authority to make rules or decisions about water allocation, to enforce rules preventing water quality degradation, or to resolve conflicts among competing stakeholders. For example, BRBC cannot require that stakeholders implement the strategies in the RBMP, nor can the organization impose government sanctions for non-compliance with plan objectives or policies [2], [9], [10].

Stewart [10], who interviewed the Board of Directors of BRBC in 2016, determined that stakeholders in BRBC recognize the complex, dynamic legal system at play in the river basin, and that it is enforced by GOA departments, municipal governments and the court system [9]. Through the RBMP, BRBC provides advice to the GOA about emergent river basin management issues and proposes management objectives and strategies for implementation by its own stakeholders. In addition, through its Board of Directors, and standing committees for policy and technical advancements, BRBC identifies and attempts to address regulatory gaps in provincial and municipal policies and laws through recommendations to government bodies in both formal and informal submissions [9], [10].

BRBC operates at the nexus of Alberta's overlapping social systems, for example law, politics, social programs and economics, and bridges what is the law with what is not the law [2], [10]. As a cross-sectoral, multi-stakeholder network with representatives from both government and civil society, BRBC operates in oscillating spaces where legal pluralism dominates, but where no one law is definitive [10].

\section{BRBC OPERATES IN COMPLIANCE WITH ALBERTA'S LEGAL SYSTEM}

One of the GOA's strategies to achieve water governance and management outcomes provided in Water For Life [17] is to develop partnerships between all levels of government and non-government actors at a river basin scale. A river basin in this context is not limited to the seven major river basins in the province, but is considered the area of land that catches precipitation and drains into a larger body of water such as a marsh, stream, river or lake [17]. Several multi-stakeholder groups, called watershed advisory and planning councils (WPACs) 
and watershed stewardship groups (WSGs) exist in Alberta and operate at different landscape scales pursuant to Water For Life. BRBC was Alberta's first WPAC and set the stage for all others in the province [9]. Several WSGs operate along the tributaries of main stem rivers, such as the Bow River, and many are members of BRBC.

However, while the GOA provided some guidance to WPACS and WSGs about preparing RBMPs, the GOA did not require or recommend that WPACS or WSGs adopt or implement Water For Life objectives or strategies when developing their plans. While BRBC is sanctioned through Water For Life to advise the GOA about river basin governance and management issues, and to create state of the basin reports and the RBMP, the organization is not compelled by law to perform any of its functions in accordance with the water governance and management legal system [17].

While generally in compliance with Alberta's complex legal system for water and land management, BRBC's most critical function in river basin governance and management is as a bridging organization, connecting stakeholders who would otherwise not be connected [2], [21]. Stewart [10] discovered that during BRBC's meetings and functions, provincial and municipal decision-makers are connected and collaborate with the stakeholders who benefit from licensed water use, approved levels of substance releases, and land use development and subdivision approvals. Through BRBC's strategic bridging processes [7], [22], government officials also collaborate with and develop trusting relationships with other stakeholders who are affected by those same licensed water uses or land use approvals [10].

\section{BRBC IS STRUCTURED AND FUNCTIONS AS A BRIDGING ORGANIZATION}

The concepts of bridging organizations and strategic bridging functions are not new [10]. In the context of environmental governance, Crona and Parker [7] summarized that a bridging organization is one that links diverse actors or groups with stakes in resource management through some form of strategic bridging process. Bridging organizations are distinct from the organizations or stakeholders they want to connect. Historically, bridging organizations emerged in the social arena in developing countries to purposefully connect disadvantaged people with resource providers and other service organizations because, otherwise those in need were not aware of those who could help them [22]. In the social arena, bridging organizations function around the globe at all scales, from local to multi-national [22].

The degree of organizational formalization and interpenetration of members within the groups makes bridging organizations different from roundtables and task forces and other informal multi-stakeholder groupings that get together to address specific resource management problems. Table 1 below illustrates the criteria that define a bridging organization according to Crona and Parker [7].

Reid [22] identified nine distinct strategic bridging functions, as follows: to maintain the status quo of an arrangement; for problem solving and transformation; to facilitate collective action; to facilitate capacity building; to increase impact or autonomy; to gain legitimacy or resources; to mediate norms among actors; to develop compromises; and to support activist voices in negotiations with dominant actors [22]. Bridging organizations have also been found necessary for social learning in transdisciplinary settings, where social learning is "learning that occurs when people engage one another, sharing diverse perspectives and experiences to develop a common framework of understanding and basis for joint action" [23].

In the context of watershed resiliency, Walker and Salt [24] summarized that bridging organizations play critical roles in natural resource management systems because "they build local institutions; horizontal linkages; vertical linkages; and increase public education and 
Table 1: Criteria that define a bridging organization [2], [7], [10].

\begin{tabular}{|c|c|c|c|}
\hline $\begin{array}{l}\text { Organizational } \\
\text { Structure }\end{array}$ & Membership & $\begin{array}{l}\text { Primary } \\
\text { Objective }\end{array}$ & Goals \\
\hline $\begin{array}{l}\text { Formalized } \\
\text { organization } \\
\text { with own } \\
\text { resources and } \\
\text { personnel. }\end{array}$ & $\begin{array}{l}\text { Varying levels } \\
\text { of stakeholder } \\
\text { diversity with } \\
\text { high degree of } \\
\text { actor } \\
\text { interpenetration. }\end{array}$ & $\begin{array}{l}\text { Develop a } \\
\text { strategic } \\
\text { bridging process } \\
\text { to connect } \\
\text { otherwise } \\
\text { unconnected } \\
\text { actors to a } \\
\text { network. } \\
\text { Third party to } \\
\text { those it seeks to } \\
\text { connect. }\end{array}$ & $\begin{array}{l}\text { 1. Provide an arena for: } \\
\text { - } \quad \text { Learning } \\
\text { - } \quad \text { ko-creation of } \\
\text { knowledge } \\
\text { - } \quad \text { Building trust } \\
\text { 2. Act as facilitators, } \\
\text { mediators, and negotiators } \\
\text { 3. Attract expertise, } \\
\text { knowledge and resources. }\end{array}$ \\
\hline
\end{tabular}

innovations. They mediate connections between otherwise unconnected actors, attract new knowledge and resources from outside the natural resource management system required for social learning and transformation, and, in doing so, increase the system's adaptability and resilience".

As explained by Crona and Parker [7], not all multi-stakeholder organizations have appropriate governance or social network structures among actors to function as bridging organizations. Stewart [10] used social network theory [25] and conducted hour long interviews with the BRBC Board of Directors and eighteen municipal representatives in the Bow Basin to determine BRBC's social network structure and approach to cross-sectoral, transdisciplinary and transboundary river basin governance. Stewart [10] created data sets from the interviews using letters and numbers to protect confidentiality of network actors. Using Pajek social network mapping software, that also analysed the different functions performed by different network actors, Stewart [10] translated the data sets into a social network map depicted in Fig. 2 below. As explained by de Nooy et al. [25] "social relations are considered channels that transport information, services, or goods between people and organizations. In this perspective, social structure helps explain how information, goods, or even attitudes and behavior diffuse within a social system. Network analysis reveals social structure and helps to trace the routes that goods and information may follow. Some social structures permit rapid diffusion of information, whereas others contain sections that are difficult to reach".

Stewart [10] observed that certain actors in the periphery of the BRBC's social network were critical bridges and brokers of information, knowledge, values, power, and influence in the wider polity. She discovered that these actors were only loosely tied to the BRBC network through other BRBC stakeholders who were all central figures with strong ties to the organization's core [10]. BRBC's particular social network structure made it possible for the organization to perform critical strategic bridging functions in river basin governance and management. BRBC was able to facilitate municipal collaboration and increased municipal participation in river basin management activities [10]. The bridging or weak ties in BRBC's periphery were critical for brokerage of information and diffusion of necessary innovations to transform how municipalities participated in river basin management activities [10]. Stewart determined that the same network structure that enabled BRBC to function as a 


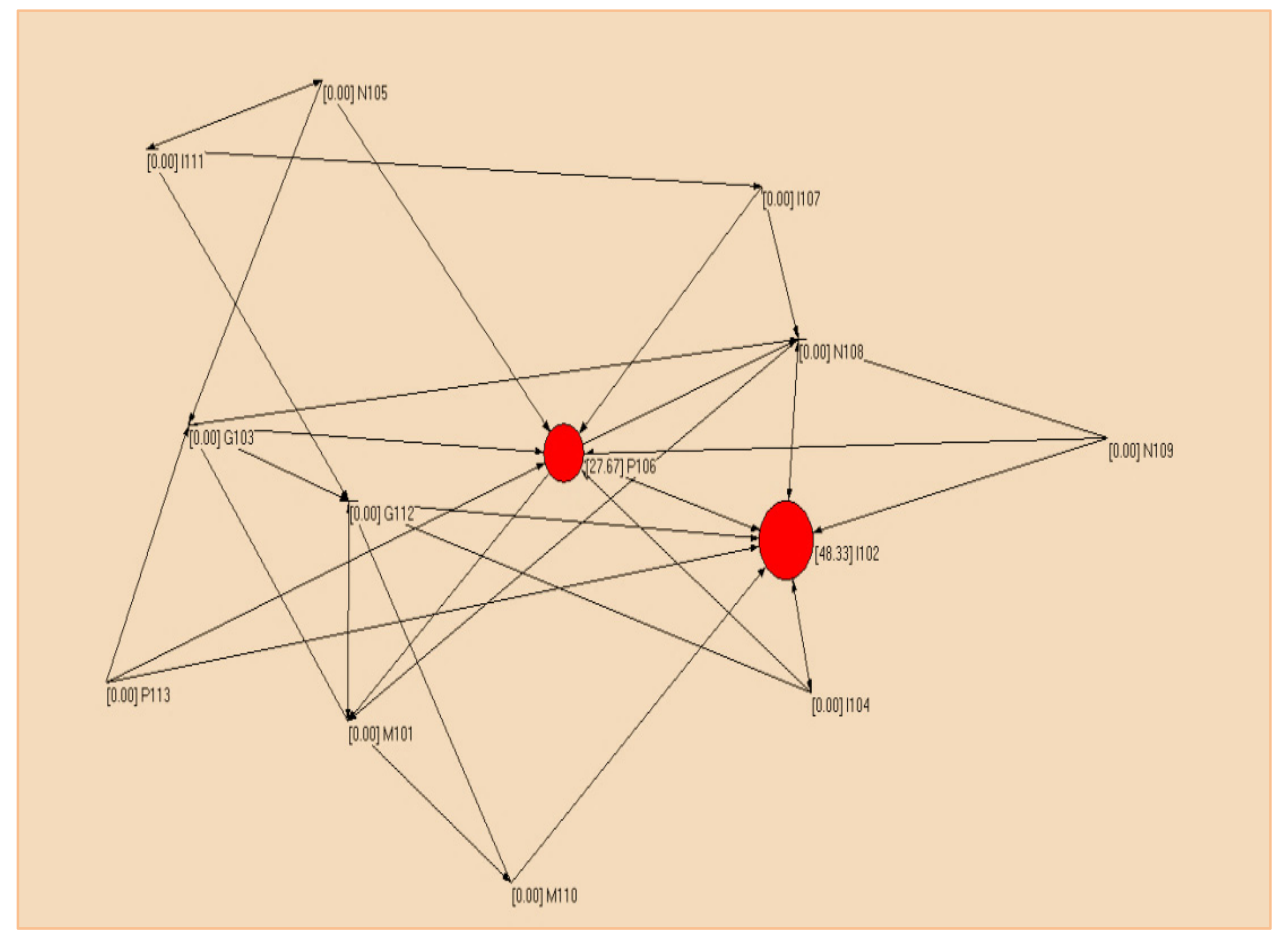

Figure 2: BRBC's social network using Pajek software [10], [25] illustrating the strong core and loosely connected actors in the network's periphery.

bridging organization also helped it achieve rapid diffusion of new information, best management practices and social learning throughout the Bow Basin [10].

BRBC did not deliberately set out to perform these strategic bridging functions [9], [10]. However, Stewart [10] verified through interviews that BRBC connected stakeholders who would otherwise not be connected; helped stakeholders identify shared resource management values and issues of concern; provided opportunities and venues for stakeholders with competing interests to build relationships of trust; collected information and transdisciplinary knowledge to create state of the basin reports and the RBMP; and provided venues and opportunities for social learning both within the organization and throughout the province [2].

Stewart [10] verified that BRBC has become a valued local river basin governance and management institution providing horizontal linkages between all levels of government, and vertical linkages between municipalities [9]. Through their quarterly information sharing forums they increase public education about emergent policy, technology and new innovations [9]. While bringing together previously unconnected representatives from different sectors, they attract new information and resources from outside the Bow River Basin. As social learning occurs, BRBC fills gaps in the complex regulatory system by showcasing strategies for improved management systems in the quarterly education forum, which eventually leads to transformations in industry practices [9]. As a result, in some cases, the RBMP's strategies have led to increased resiliency in the basin, and flexible and adaptive processes for achieving shared objectives described in the plan [9], [10], for example several 
municipalities have adopted riparian land and wetland conservation and management strategies as set out in the BRBC RBMP [6].

Stewart [10] concluded that with its strong history and recognition as a WPAC under Alberta's Water For Life, BRBC's social network has the structural integrity required to perform critical strategic bridging functions necessary for effective river basin governance and management. As a provincially recognized and funded organization with GOA stakeholders at the consensus decision-making table, BRBC is a sustainable organization.

\section{BRBC'S CRITICAL ROLE IN RIVER BASIN MANAGEMENT}

Generally, when cross-sectoral, multi-stakeholder networks of affected parties, such as the BRBC participate in collaborative processes for river basin governance and management, they build trust among stakeholders and influence stakeholder behaviours [2], [7], [10], [21][23], [26], [27]. BRBC has a good reputation for consensus-decision making processes and establishing agreement among self-interested parties who are all competing for the limited supply of water in the basin [9]. In this way, BRBC wields some power and influence with decision-makers as the go-to organization for recommendations for policy development to fill regulatory gaps, and strategies to implement policy through best practices [9], [10].

Stewart [10] determined that BRBC performs four critical strategic bridging functions [2], [7], [21], [22], [26], [27]. First, BRBC brokers transdisciplinary knowledge, providing opportunities for information sharing, co-generation of new transdisciplinary knowledge, and co-creation of management plan objectives and strategies. Annual general meetings, workshops, committee projects and programs bring stakeholders together to work through complex management issues [2], [9]. Through quarterly education forums, BRBC shares emergent information and knowledge about resource management technology, management planning and implementation, stewardship activities, and new provincial-scale policy and legislation [2], [9], [10]. BRBC is noted for the critical work done by standing committees for communications, policy development and technical advancement [9]. Actors in BRBC's network periphery share information generated through BRBC's collaborative processes with other WPACs and WSGs in other river basins. The GOA is not in the position to share information and co-create knowledge necessary for social learning and system transformation on its own.

Second, BRBC brokers shared river basin management values. The organization provides venues and resources to mediate between values, negotiate desired outcomes, create agreed upon management scenarios, and reach consensus on strategies to improve river basin management [2], [9], [10]. These values have emerged over time through connections made between stakeholders with competing interests who share common concerns about water scarcity or degradation and land use management adjacent to water bodies. BRBC's consensus decision-making processes help members to identify and prioritize cross-sectoral management values. The GOA's substantive regulatory system is unable to differentiate between and manage for values basin by basin, as laws and regulations necessarily apply right across the province as one-size-fits-all.

Third, BRBC brokers power and influence. BRBC influences provincial and municipal decision-makers in the river basin by providing venues and opportunities for interactions between stakeholders and government officials, and through presentations and written submissions. Stewart [10] identified that social learning that took place through BRBC collaborative processes was instrumental in the systemic transformation in how municipalities regulated and controlled human activities that may negatively impact land, water, and air quality. Without such transformative action, municipal land uses might have continued to fragment the structural and functional connectivity of the landscape at the nexus 
of water and land use [1], [2], [9], [10]. While the GOA has promulgated provincial land use policies for conserving and managing water and natural resources since the Municipal Government Act [18] was enacted in 1994, these policies were not being applied by municipalities with any consistency in the Bow Basin [18], [19].

Last, BRBC promotes voluntary collective action for the improvement of the health and resiliency of the river basin. Stakeholders who attend BRBC's quarterly forums are exposed to emergent policy and technical advancements and choose to implement best management practices when and where they can. The GOA cannot manage the basin by themselves through substantive regulatory processes, and the partnership with BRBC has proven beneficial to the health, sustainability and resiliency of the basin [9].

\section{CONCLUSION}

In this Canadian context, BRBC is structured and functions as a bridging organization, performing critical strategic bridging functions for effective governance and management of land and water in the Bow Basin. Through collaborative processes, provincial and municipal levels of government are connected with various stakeholders with competing interests in how water and land are to be used in times of rapid growth and water scarcity.

BRBC helps stakeholders identify shared interests and common values for river basin management. It also plays a critical role in social learning and policy development. Gaps in provincial and municipal policy and law are identified through BRBC governance processes and recommendations are made to the GOA for addressing those gaps. The co-creation of the state of the basin reports and the river basin management plan lead to new co-created transdisciplinary knowledge, best practices and changes in how people interact in the environment. Significantly, BRBC influences increased municipal participation in river basin management activities throughout the basin.

In Alberta, with its complex legal system, provincial and municipal governments understand the value of partnering in collaborative governance processes with BRBC and other WPACs around the province. This paper used BRBC's as the demonstration context to discuss the requisite social network structure for WPACs to perform several critical strategic bridging processes for effective watershed governance and management. Further research may be required to determine if Alberta's other WPACs have a similar social network structure and perform similar functions.

It may be that GOA may no longer be able to manage complex, dynamic human interactions at the river basin scale that impact the quality and quantity of scarce water resources through substantive regulatory regimes alone. They may require active participation of bridging organizations working alongside and enhancing the effectiveness of the regulatory system through voluntary collective action. The local institutions that have emerged in Alberta, such as BRBC and other WPACs, and the horizontal and vertical linkages between actors that have been made have helped to increase public awareness of the need to collaborate to solve complex river basin management problems. Solving these problems needs to be done at a basin-scale where shared community values can be used to establish trade-offs and develop triggers and thresholds for keeping the quantity and quality of water resources within desired bounds. Bridging organizations in Alberta's river basin governance and management system are critical to attracting knowledge and resources otherwise not available to governments, and for introducing adaptions for system transformation. Without system transformation, the resiliency of the Bow Basin may be put at risk during periods of sustained rapid growth in population and economic development. 


\section{REFERENCES}

[1] Tyler, M.E. \& Quinn, M., Identifying social-ecological couplings for regional sustainability in a rapidly urbanizing water-limited area of western Canada. Wessex Sustainability Development and Planning VI, WIT Press: Southampton and Boston, pp. 175-191, 2013.

[2] Stewart, J. \& Tyler M.E., Bridging organizations and strategic bridging functions in environmental governance and management. International Journal of Water Resources Development, pp. 1-24, 2017.

[3] Government of Alberta, Economic outlook: Overview. www.alberta.ca/budgeteconomic-outlook.aspx\#toc-9. Accessed on: 2 Jan. 2019.

[4] AMEC, South Saskatchewan River Basin in Alberta: Water Supply Study, Alberta Agriculture and Rural Development: Lethbridge, Alberta, 2009.

[5] Government of Alberta, Water Act, R.S.A. c.W-6. www.qp.alberta.ca/ documents/Acts/w03.pdf. Accessed on: 20 Dec. 2018.

[6] Government of Alberta, South Saskatchewan Regional Plan 2014-2024. https://open.alberta.ca/dataset/460ac866-4416-4d77-a25a-a02fab85a6ec/resource/ 8261ce03-aa0f-4621-8e2d-c610a72ac37c/download/south-saskatchewan-regionalplan-2014-2024-february-2017.pdf. Accessed on: 15 Dec. 2018.

[7] Crona, B.I. \& Parker, J.N., Learning in support of governance: Theories, methods, and a framework to assess how bridging organizations contribute to adaptive resource governance. Ecology and Society, 17(1), 2012.

[8] Pomeroy, J.W., Stewart, R.E. \& Whitfield, P.H., The 2013 flood event in the South Saskatchewan and Elk River basins: Causes, assessment and damages. Canadian Water Resources Journal, 41(1-2), pp. 105-117, 2016.

[9] Stewart, J. \& Bennett, M., Integrated watershed management in the Bow River basin, Alberta: Experiences, challenges, and lessons learned. International Journal of Water Resources Development, 33(3), pp. 458-472, 2017.

[10] Stewart, J.A., reflexive legal framework for bridging organizations in regional environmental governance and management. PhD dissertation, University of Calgary, 2016.

[11] Stewart, J., Reflexive approaches to lawmaking to legitimize environmental bridging organizations in the Calgary region. Journal of Environmental Law and Practice, 31(1), pp. 37-77, 2017.

[12] Teubner, G., Substantive and reflexive elements in modern law. Law and Society Review, 17(2), pp. 239-286, 1983.

[13] Tamanaha, B.Z., Understanding legal pluralism: Past to present, local to global. Sydney Law Review, 30(3), pp. 375-411, 2008.

[14] Environmental Protection and Enhancement Act, c. E-12. www.qp.alberta.ca/ documents/acts/e12.pdf. Accessed on: 4 Jan. 2019.

[15] Government of Alberta, Approved Water Management Plan for the South Saskatchewan River Basin (Alberta). https://open.alberta.ca/publications/ 0778546209. Accessed on: 4 Jan. 2019.

[16] Bow River Basin Council, Bow Basin Watershed Management Plan. Phase 1: Water Quality. Bow Basin Watershed Management Plan Steering Committee, 2008. https://brbc.ab.ca/our-activities/bow-basin-watershed-management-plan. Accessed on: 4 Jan. 2019.

[17] Government of Alberta, Water For Life: Alberta's Strategy for Sustainability. https://open.alberta.ca/publications/0778530582. Accessed on: 4 Jan. 2019. 
[18] Government of Alberta, Municipal Government Act, R.S.A. 2000, c.M-26 and regulations. www.qp.alberta.ca/documents/Acts/m26.pdf. Accessed on: 3 Jan. 2019.

[19] Stewart, J., Do recent amendments to Alberta's Municipal Government Act enable management of surface water resources and air quality. Alberta Law Review, 55, pp. 1009-1044, 2017.

[20] Luhmann, N., Law as a Social System, Oxford University Press: New York, 2004.

[21] Rathwell, K.J. \& Peterson, G.D., Connecting social networks with ecosystem services for watershed governance: A social-ecological network perspective highlights the critical role of bridging organizations. Ecology and Society, 17(2), pp. 24-45, 2012.

[22] Reid, K.E., Building a framework for institutional change. PhD dissertation, University of Texas, Austin. p. 48, 2004.

[23] Schusler, T.M., Decker, D.J. \& Pfeffer, M.J., Social learning for collaborative natural resource management. Society and Natural Resources, 16(4), pp. 309-326, 2003.

[24] Walker, B. \& Salt, D., Resilience Thinking: Sustaining Ecosystems and People in a Changing World, Island Press: Washington, DC, 2006.

[25] de Nooy, W., Mrvar, A. \& Batagelj, V., Exploratory Social Network Analysis with Pajek, 2nd ed., Cambridge University Press: Cambridge, p. 139, 2011.

[26] Bodin, O. \& Prell, C. (eds)., Social Networks and Natural Resource Management: Uncovering the Social Fabric of Environmental Governance, Cambridge University Press: New York, 2011.

[27] Berkes, F., Evolution of co-management: Role of knowledge generation, bridging organizations and social learning. Journal of Environmental Management, 90, pp. 1692-1702, 2009. 